\title{
Den lilla ondskan och det kommunistiska arvet
}

\section{Fredrik Blomqvist}

Det är Prag 1950. Den tjugotvåårige stridspiloten Miroslav Dvořáček som flydde till Tyskland efter den kommunistiska kuppen två år tidigare har återvänt som spion för den amerikanska säkerhetstjänsten. Hans uppgift är att söka kontakt med en högt uppsatt ingenjör vid ett kemiföretag i staden och rekrytera honom som informatör. Dvořáček möter i staden sin barndomsvän Iva Militká som tillsammans med pojkvännen Miroslav Dlask studerar vid Karlsuniversitetet. Det blir ett glatt återseende och medan Dvořáček söker efter ingenjören lämnar han sin resväska i deras studentkorridor. Dvořáčeks försök att lokalisera mannen visar sig fruktlösa och han bestämmer sig så småningom att ge upp och försöka igen nästa dag. Men när Dvořáček återvänder till studentbostaden möts han av två poliser istället för sin vän Militká. Förrådd blir han arresterad och dömd för spioneri, desertering och högförräderi. Ett långt fängelsestraff väntar där Dvořáček bland annat tillbringar fjorton år i de ökända urangruvorna. Det föregående är inte handlingen i en spionroman eller thriller, utan en av många liknande händelser i det kommunistiska Tjeckoslovakien. Det här var däremot ett fall som skulle få stor publicitet långt senare.

\section{Fallet Milan Kundera}

I oktober 2008 publicerade tidskriften Respekt en artikel där författarna hävdade att de funnit vem det var som angav Dvořáček. Avslöjandet fick genomslag både i Tjeckien och utomlands, det senare underlättades av att tidskriften såg till att översätta artikeln till engelska på sin nätupplaga. Jag kom i kontakt med frågan genom att den plockades upp av ett nätverk för europeiska kulturtidskrifter - Eurozine. Deras mål är att spegla och sammanföra den politiska och kulturella debatten i Europa och som ett led i detta brukar artiklar från tidskrifterna som ingår i nätverket läggas upp på nätet. Några översatta tjeckiska artiklar som rörde Respekts avslöjande lades också upp, kompletterat med länkar till artiklar på annat håll.

Anledningen till uppståndelsen kring artikeln var att den utpekade inte var någon mindre än den kände författaren Milan Kundera som i början av 50-talet också var student vid Karlsuniversitetet. Anklagelserna grundades på en rapport från en lokal polisstation, funnen i ett arkiv hos Institutet för studier av totalitära regimer, där Kundera står som anmälare. Det som ansågs ha hänt var att Dlask hade sett Dvořáček som en potential rival och berättat om besöket för Kundera som i sin tur gått till polisen. Kundera som blivit känd som en dissident och kritiker av det kommunistiska systemet - efter Warszawapaktens invasion emigrerade han till Frankrike 1975 - var en tacksam måltavla för den som vill putta ner en moralisk auktoritet från hans piedestal. Emot honom ställdes olika omständigheter i hans liv. Han hade inte kommunicerat med medierna på tjugofem år och endast lämnat ett kort nekande till anklagelserna. Dessutom har Kundera sedan han bosatt sig i Frankrike - numera med franskt medborgarskap - endast sällan och diskret besökt Tjeckien. Sedan 1993 hade han till och med övergett tjeckiskan i sitt författarskap. Hänvisningar gjordes till hans författarskap där angiveri och förräderi varit ett viktigt tema och därför kunde vara ett tyst medgivande. Hans syn på författarskapet och romanen - där den ska läsas för sig själv, utan hänvisningar till författaren - har tagits som intäkt för ett försök att avlägsna sig från sitt förflutna.

De som gav Kundera sitt stöd, bland annat den tidigare presidenten Václav Havel, har pekat på omständigheterna kring dokumentet. Dels att den saknades i hans egen akt hos säkerhetspolisen 
och att både id-nummer och underskrift saknas på anmälan. Varken Militká, Dlask eller Kundera blev heller förhörda av polisen. Litteraturkritikern Zdenek Pesatt meddelade några dagar efter originalartikelns publicering att Dlask på femtiotalet berättade för honom att han informerat polisen om en misstänkt spion. När det också kunde beläggas att Dlask varit i kontakt med säkerhetspolisen var för en del saken avgjord. En av dem som stod bakom artikeln var dessutom släkt med Dlasks änka, Militká, vilket väckte frågan om det kunde handla om ett försök att minska den avlidnes skuld. Utöver tekniska detaljer vände sig Kunderas försvarare mot den starka betoningen på gott och ont i anklagelserna, med Kundera som ondskefull lakej och Dvořáček som ädel frihetskämpe. De menade att en eventuell angivares handlande måste bedömas utifrån 1950-talets ramar, att det i den tidens samhälle rådde en kommunistpatriotisk stämning där misstänksamhet mot utomstående odlades och där stränga straff kunde utdömas för den som upptäckt men inte rapporterat någon eller något misstänkt.

\section{Att minnas det förflutna}

Affären är i sig ett exempel på en konflikt om hur historien ska tolkas, men är inte bara en fråga om Kunderas skuld eller oskuld. Det handlar också om tjeckernas hantering av sitt förflutna. Litteraturprofessorn Miroslav Balastik ger en bild av det tjeckoslovakiska samhället efter 1968 för att sätta debatten i sitt sammanhang. Invasionen krossade slutgiltigt alla illusioner som tidigare kunde ha funnits om kommunismen. Den styrande regimen, vars maktinnehav helt vilade på Moskvas stöd, slöt dock ett slags informellt avtal med befolkningen. Medborgarna skulle å sin sida uppfylla vissa formella förpliktelser, som medlemskap i vissa föreningar, deltagande i valen och hissande av sovjetiska flaggor vid lämpliga tillfällen. I gengäld kunde få de goda positioner, utbildning för barnen och semestrar i Jugoslavien. Resultatet blev en stabilitet i samhället, men det innebar också att medborgarna kom att bära på skamkänslor över sin medgörlighet. Den misstänksamhet som medborgarna kände mot sig själva och andra gjorde gränsen mellan individen och regimen otydlig vilket hjälpte regimen att överleva. När den sedan föll under "sammetsrevolutionen" 1989 var det med hjälp av en ny generation som inte ville veta av avtalet. Men någon fullständig uppgörelse med det som hade varit blev det inte utan regimskiftet skedde, som i Polen, snabbt och smärtfritt (Václav Havel valdes faktiskt av den sittande riksdagen). Antingen ställdes de avsatta ledarna aldrig inför rätta eller så fick de sina mål avskrivna efter att de dragits i långbänk. Kommunistpartiet blev heller inte förbjudet, även om ungdomsförbundet tvingats upplösas 2006 med motiveringen att det hade kollektivisering på programmet.

Det försoningsfulla maktskiftet gjorde att allt gick smidigt och fredligt tillväga. Men det innebar också att frågan om ansvar blev satt på undantag och därigenom hämmades processen med att bearbeta historien och skilja regimen och folket åt. De som fått ta skulden och ansvaret är inte de som suttit på beslutsfattande positioner, vars inblandning ursäktades med att de bara gjorde sitt jobb, utan de som givit regimen sitt dolda stöd - informanterna och angivarna. Det fick sitt uttryck 1992 när anti-kommunisten Petr Cibulka publicerade bästsäljande listor över alla säkerhetstjänstens agenter och informatörer. Bland namnen fanns många kända personer: skådespelare, intellektuella, präster och framstående dissidenter. Trots oklarheter kring hur listorna tillkommit mötte de inget motstånd från officiellt håll och en jakt på skyldiga kunde börja. Resultatet för de anklagade blev att de förlorade vänner, prestige och ibland jobb. En lag infördes med syfte att de som varit medlemmar i kommunistpartiet eller samarbetat med regimen skulle förhindras från att inneha offentliga positioner. Men det visade sig sedan att listan även innehöll personer som bara 
omnämnts som möjliga informatörer och att den inte heller informerade om huruvida informationen hade fåtts fram via tvångsmetoder. De anklagade hade dock svårt att få upprättelse då arkiven var stängda för kontroll, och något större intresse för de individuella historierna visades inte. Det ställer Balastik i kontrast till reaktionen efter anklagelserna mot Kundera, där stämningen från det tidiga 1990-talet var borta. Det tjeckiska samhället letar inte längre efter skyldiga, menar han, det tvivlar istället för att döma. En ny fas i det post-kommunistiska Tjeckien har nåtts där samhället vill höra historierna bakom det som hänt.

Tidningen Respekts redaktör Martin M. Šiemečka har en annan syn på saken. Han ser fallet Kundera som ett led i en uppgörelse med den vedertagna bilden av kommunistregimen som ett sofistikerat fängslande av anden som förgiftade samhället, den bild Kundera och hans fars generation har stått för, där skönlitterära berättelser ersatt riktiga minnen. Istället vill han se en fokus på den lilla, banala ondskan som finns i människors handlingar och att historien istället för att ses som ett avslutat kapitel ska användas till att söka efter nyckeln till friheten och undvika risken för upprepningar. Ett exempel på en uppgörelseprocess kan ses i Polen, även om den måhända har dagspolitiska förtecken. En rättegång har startats mot den före detta generalen och presidenten Wojciech Jaruzelski angående hans ansvar för undantagstillståndet 1981. Lech Walesas förflutna har granskats i en nyutkommen bok där det hävdas att han på 70-talet lämnade information till säkerhetstjänsten om arbetskamrater i utbyte mot betalning.

Jag räknar mig nog till dem som gärna ser att Tjeckien gör upp med sitt förflutna för att slutligen ta sig framåt. Kanske något liknande Sydafrikas Sannings- och försoningskommission, som hade till uppgift att genom att vädra apartheidbrotten en gång för alla bilägga potentiella konflikter. Det hade varit ett sätt att bearbeta det som hänt, även om den efterföljande hanteringen av historien och historieskrivningen i Sydafrika präglats av en viss glömska och överslätande i förhållande till missdåden. Hur som helst behövs det en lösning där hela samhället analyseras, inte bara fall med kända personer som kan ge publicitet, som det lite cyniskt kan sägas ha varit hittills. För den som vill ta itu med historien kanske Václav Havels ord kan vara ett gott råd: "Var försiktig när du tolkar historien! Annars kan du göra mer skada än nytta. Precis som din farfader gjorde."

\section{Referenser}

Abrahám, Samuel, A trace of metaphysics? $<$ http://www.eurozine.com/articles/2008-10-22-abraham-en.html>. Avläst den 20/3 2009.

Balastik, Miroslav, Two stories. <http://www.eurozine.com/articles/2008-11-07-balastik-en.html >. Avläst den 20/3 2009.

Havel, Václav, Two messages. $<$ http://www.salon.eu.sk/article.php?article=732-two-messages-english >. Avläst den 20/3 2009.

Kalinowski, Wojtek, Fallet Walesa delar Polen. $<$ http://www.dn.se/dnbok/fallet-walesa-delar-polen-1.466531>. Avläst den 20/3 2009.

Pallas, Hynek, Polsk historiedebatt - locket på i Tjeckien. $<$ http://www.svd.se/kulturnoje/mer/kommentar/artikel_2176627.svd>. Avläst den 20/3 2009.

Šiemečka, Martin M., My Father's Generation. <http://www.salon.eu.sk/article.php? article=805-my-father-s-generation\%E2\%8C\%A9=EN > . Avläst den 20/3 2009

Šiemečka, Martin M., The Owner of the Key. $<$ http://english.respekt.cz/The-Owner-of-the-Key-2741.html>. Avläst den 20/3 2009.

Třešňák, Petr \& Hradilek, Adam, Milan Kundera's denunciaton. $<$ http://english.respekt.cz/Milan-Kunderas-denunciation-2742.html>. Avläst den 20/3 2009. 